\title{
The Rogue from Within: The Denial of Torture in Italian Prisons
}

\section{Vincenzo Scalia}

\section{Critical Criminology}

The official Journal of the ASC Division on Critical Criminology and the ACJS

Section on Critical Criminology

ISSN 1205-8629

Crit Crim

DOI 10.1007/s10612-015-9299-y

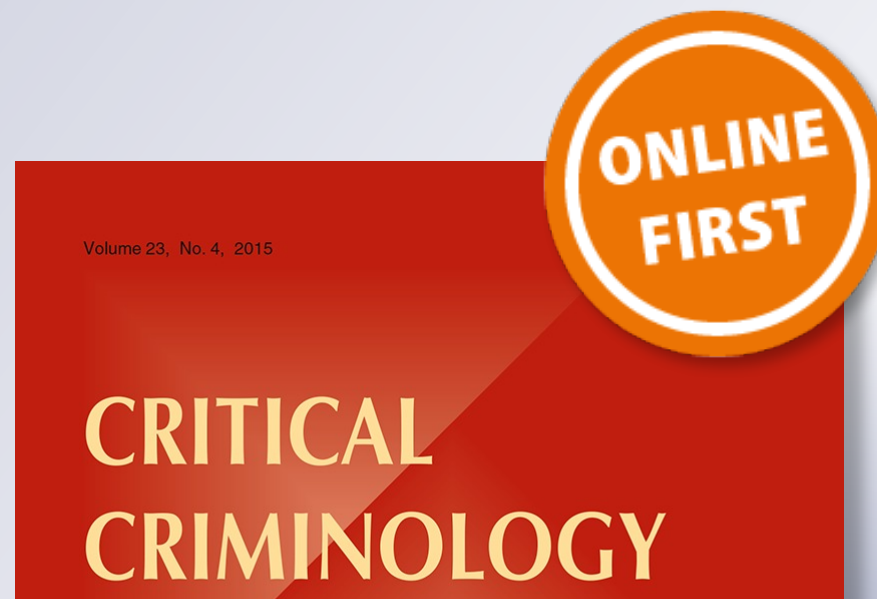

An International Journal

Editor-in-Chief: David Kauzlarich

Special Issue: Climate Change from a Criminological Perspective Guest Editors: Ronald C. Kramer and Rob White

The official journal of the ASC Division on Critical Criminology

Springer 
Your article is protected by copyright and all rights are held exclusively by Springer Science +Business Media Dordrecht. This e-offprint is for personal use only and shall not be selfarchived in electronic repositories. If you wish to self-archive your article, please use the accepted manuscript version for posting on your own website. You may further deposit the accepted manuscript version in any repository, provided it is only made publicly available 12 months after official publication or later and provided acknowledgement is given to the original source of publication and a link is inserted to the published article on Springer's website. The link must be accompanied by the following text: "The final publication is available at link.springer.com". 


\title{
The Rogue from Within: The Denial of Torture in Italian Prisons
}

\author{
Vincenzo Scalia ${ }^{1}$
}

(C) Springer Science+Business Media Dordrecht 2015

\begin{abstract}
In October 2009, Stefano Cucchi was beaten to death by prison guards while in custody. Italian public opinion toward prisons changed because of this event. Civil society organizations rose the level of awareness by showing how routine these abuses have become. This paper discusses the case of prisoners tortured in the prison of Asti, near Turin. Through the use of Stanley Cohen's categories of denial, it will be shown how force relations inside prison make abuses possible.
\end{abstract}

\section{Introduction}

In October 2009, Stefano Cucchi was beaten to death while in custody at the old prison of Rome, Regina Coeli. Since then, Italian public opinion has become increasingly aware of the reality of institutional violence within prisons, and of its often tragic outcome-both psychological and physical damage to the victims, or, even worse, death. Such belatedness in acknowledging the extent of the problem is due to the attitude of Italian prison officers and administrators in considering the penitentiary a domain to be hidden from public opinion (a legacy of the authoritarian subculture dating back to Fascism), and to the so-called "culture of emergence" (Mosconi and Sarzotti 2005). The latter is an aspect of Italian public opinion that has grown in the last 30 years as a reaction to political terrorism, institutional corruption, and organized crime. A stand for harsh measures has resulted in a general acceptance of and justification for judicial and penal figures acting in violation of the law.

The violent repression of political rallies during the G8 Summit in Genoa (De Gregorio 2005), in 2001, paved the way for a public debate about Italian police forces' modus operandi. Public indignation at the time focused more on matters of public order than on what happened inside prisons, which enjoyed a degree of impunity due to the moral panic

Vincenzo Scalia

Vincenzo.Scalia@winchester.ac.uk

1 University of Winchester, Medecroft Annex 4, Sparkford Road, Winchester,

Hampshire SO22 4NR, UK 
that, since the 1990s, had spread across the Western world, legitimating the harsh treatment suffered by many inmates.

The death of Stefano Cucchi (Manconi 2012) then became the turning point around which public opinion perceptively changed. It prompted organizations active in the promotion of human rights within prisons, such as Antigone, A Buon Diritto, the Radical Party, and the Italian branch of Amnesty International to bring to the fore the issue of abuse carried out by penitentiary employees. The ongoing economic and political crisis also resulted in a crisis of the securitarian paradigm, making room for the sensitization of public opinion on prison abuses. Mobilization of civil society made it possible to call for Parliament to pass a law that would make torture illegal. There is still a lacuna in Italian law concerning torture, despite the many treaties signed by Italy that ban this crime (Gonnella 2013).

This paper will deal with inhumane treatment of inmates at the Italian prison in Asti, near Turin. It will focus on the trial against five prison officers accused of violence against two prisoners. While this trial ended with the acquittal of the defendants, the judge clearly stated in his verdict that the prison guards were guilty, but because Italy had no law against torture, it was not possible to convict them. A similar episode happened in December, 2009, in Teramo, where a prison officer beat an inmate (www.larepubblica.it, 2009) outside his cell. The victim reported the abuse to the judges, and another prisoner, who had witnessed what happened, agreed to testify. The death of the witness, which occurred in controversial circumstances, slowed the inquiry. A few months later, the prosecutor decided not to proceed.

The paper will focus on the strategies of denial that both the prison guards and the prison director adopted to defend themselves from the charges. Drawing on the work of Kauzlarich et al. (2001), I will show how the perpetrators of what is called domesticdomestic governmental crime (DDGC) enact their strategies of denial both by denying the harm they caused and by assessing the effectiveness of their policies. Developing the scheme of explicit and interpretative denial elaborated by Cohen (2005, Italian edition), I will show how the explicit denial, which I shall term internal denial, is the outcome of a specific subculture of penitentiary employees, who believe abuse is a means of maintaining order by gaining the respect of prisoners. This subculture also involves the complicity of those prisoners who do not report beatings. This form of denial is internal to the extent that it develops within the penitential domain. I will show how interpretative denial, or external denial, consists of strategies officers work out once public opinion has become aware of what happens in prisons. In this case, the denial is "external" because it relates to the need to justify, in public opinion, atrocities (p. 132). I will conclude by arguing that a different type of training of prison guards, and the institution of an Independent Prison Ombudsman, are necessary to limit these cases, as is the passing of an anti-torture law. The main source of this article is the official file of the trial itself. I had the opportunity to read it and analyze thanks to my friend and lawyer Simona Filippi, whom I would like to thank.

\section{The Discovery of Abuse: The Prison of Asti and the Context of the Italian Penitentiary}

In early 2005, magistrates in Asti were investigating the alleged involvement of C.B., an officer of the Asti prison, in a network of drug dealers who sold narcotics in the prison. For this reason, investigators wiretapped both the car of L.P., a colleague and close friend of 
C.B., and the mobile number of the latter. M.G., another prison officer, calls C.B., and informs him about something that happened in the prison (Tribunale di Asti 2012):

I have great news for you! Our friend [A.C., an inmate] nearly died [...] he's in coma [...] he hanged himself!

C.B. asks what happened to C.R., another inmate, calling him "the other bastard," and M.G. answers,

Nothing. He's enjoying life.

The phone call ends, and C.B. comments on the matter with L.P., giving the colleague his opinion of the facts

f...k, $[\ldots]$ I do to you what you do to me [...] if you're a man, you've gotta take on the inmate one on one [....]. If he slaps me I have to react [...]. I'm not a s...t, so I don't report him to the director [...] I just take off my jacket and fight one on one, if he can fight I take his punches, I don't report him [...] a lot of colleagues just talk, then run away [...] it's easy to beat someone when you are 5 against one [...] you are not a man [...] if you beat them when you are one on one, you avoid problems [...] the Great Strumpf [i.e., the magistrate] will enquire [...].

C.B.'s comments tell us a lot about the context of Italian prisons. I am aware that prisons across the world are places where prison officers often engage in inhumane and degrading practices (Goldson 2006), which result in systematic violations of human rights. Liebling and Arnold (2005), for instance, have exposed the gap between formal rules and daily life in prisons. Convict criminologists (Irwin 2004) have also shed a light on the harshness of prison life. In any event, the existence in many countries of independent inspection offices, such as prison ombudsmen, allows public opinion to become aware of what goes on inside prisons, and to prosecute any violation that inspecting officers do discover. Moreover, the punishment for abusers through anti-torture laws, might work as an instrument of limitation and prevention of violent and abusive behaviors. Italy still lacks both an Independent Prison Ombudsman (institution of which was approved by Parliament only in early 2014), and an anti-torture law. Inspection of prisons by NGOs, such as Antigone, dates back to the late 1990s, and the Ministry of Justice still limits inspections: NGO observers cannot speak to inmates, and cannot visit the rows wherein serious offenders, such as mafia members, serve their sentences. The combined lack of control and anti-abuse laws are consonant with the law-and-order attitude of public opinion. The management of prisons relies on informal rules, which are typically stacked against prisoners.

The prison guard describes beatings as routine business, at least in the prison where he works. As Goffmann (1982, Italian edition) points out, prison as a social institution denotes its own symbolic frame, with its own set of rules, rituals, expectations, and roles, partly established and partly negotiated by the actors of the frame. The rules of the symbolic frame might often be at odds with the general rules of the wider society, but they are what daily life in total institutions relies on.

The prison in Asti has a set of rules that officers, doctors, directors, social workers, and prisoners must abide by. First, it is normal to beat prisoners who are in solitary confinement. Second, neither the offenders nor the victims can report the facts to judicial authorities. Third, the director and the doctor must deny that violence occurs in prison. As Cohen (2005, p. 35) points out, the sharing of a culture of denial through a triangular relationship among the victims, the offenders, and those who observe makes it difficult to ascertain the truth. This is an important aspect of denial in the contemporary age, 
particularly in total institutions, which are difficult to inspect. Finally, the prison in Asti shares another rule with other Italian prisons (Gonnella 2013, p. 47). Prisoners who behave violently suffer the punishment of solitary confinement. They are put inside the so-called celle lisce (bare cells) for an arbitrary amount of time. There is no furniture in this kind of cell, and prisoners cannot have shoestrings or belts, so they cannot attempt to take their own lives. The Committee for the Prevention of Torture of the Council of Europe has warned the Italian government several times about the illegality and inhumanity of the bare cells (www.cpt.coe.int, 2012). Italian penitentiary law 354/1975 states, in article 6, that prisoners must live in properly furnished cells, and, in article 40, that it is the Disciplinary Board that must decide on moving a detainee to solitary confinement, after doctors have certified that he or she can withstand isolation. Article 33 does not mention bare cells as a form of punishment. Presidential Decree 230/2000, in article 73, strictly disciplines isolation, stating that inmates are entitled to humane accommodation, including the same kind and amount of food as fellow inmates. The unlawfulness of bare cells renders their use even more abusive. After briefly describing the context of the prison in Asti, we should now attempt to illustrate and analyze how the denial of responsibilities by the different actors took place during the trial.

\section{From Isolation to Normalization: The Construction of Internal Denial}

This chapter will deal with the way the offenders and the observers faced the trial. I call offenders the prison officers who took part in the beatings, either individually or as part of a team. I call observers the director of the prison and the doctor, who testified in the trial. Another observer is the head of the social workers, who saw C.R. bruised after the beatings, and testified to the jury concerning the fact. I will now focus on the two levels of denial that operate: the internal level consists of the routine bureaucratic procedures issued by the prison administration to cover up the beatings. The external level of denial concerns the strategies enacted to hide what happened from the judges. The graphic below shows the steps of denial.

\begin{tabular}{ll}
\hline Internal (literal) & External (interpretative) \\
\hline Isolation & Uprightness \\
Neutralization of victims (prisoners) & Necessity \\
Normalization & Denial that there is a victim \\
Subjugation & Contextualization \\
& Comparison \\
\hline
\end{tabular}

In order to have a more articulated understanding of the matter, it is necessary to illustrate what happened. On December 10th, 2004, A.C., an inmate of the Asti prison, quarreled with prison officer C.B. C.R., another inmate, tried to keep the two from fighting. As a result, C.B. sent A.C. back to his cell and ordered C.R. to take off all his clothes. The inmate obeyed, and was then taken to solitary confinement on the bottom floor of the prison by other guards. Once in the bare cell, where he stayed for 2 months, C.R. suffered regular food deprivation and systematic beatings, and had his clothes returned to him only after the second day. C.B. also tore off C.R.'s ponytail with his bare hands. A.C. received 
similarly abusive treatment a few days later. Officers stripped him, took him to the bare cell, fed him with only stale bread and water for the first 2 days, then gave him limited amounts of food, as they did with C.R. Unlike his fellow inmate, A.C. spent only 20 days on isolation row, but could not endure the harshness of the abuse, and attempted suicide. Another important aspect to consider concerns the psychological and physical conditions of the two inmates, who were both drug addicts and were undergoing buprenorphine treatment at the moment of the abuses (Tribunale di Asti 2012, p. 89).

A.F., a prison guard who testified against his colleagues, explicitly states that a team of prison guards in charge of beating the prisoners under isolation existed in the Asti prison:

When an inmate proved to be particularly aggressive, he was sent to solitary confinement. Then a team of six guards went to beat him, and this kind of punishment went on for a few days [...].

Other guards could work in the isolation row while on duty, but their only task was that of surveillance, though they became aware of what happened in two ways: first, their colleagues who were accused of the beatings told the others what they did and why. Second, the inmates who had suffered the beatings asked to see the doctor. It is at this stage that we come across internal denial, i.e., a strategy of denial that such prison employees as the guards, the director, and the prison doctor mold by adopting strategies of literal denial (Cohen 2005, p. 132). I call it "internal" because the strategy of denial the actors use serves the purpose of building a narrative that only those who live and work in the prison can share. As Zimbardo (2009, p. 383) points out, the situational force of a prison drives the dispositional force of prison employees, i.e., the need to be accepted in a group. Prison employees, at this stage, do not yet know they are going to face a judicial enquiry and a trial. Therefore, they are trying to build a truth that everyone inside the prison can share, by turning a violation of human rights into a routine fact. The building process works through a manipulation of facts, the dynamics of group identity, and the need for acceptance proves to be a powerful driving force in this respect. Group identity makes the burden of violent acts lighter, boosts solidarity among the group members, and isolates other actors. As Kauzlarich et al. (2001, p. 188) point out, victimizers always try to achieve bureaucratic, organizational or institutional goals, and it is necessary to analyze how they pursue this.

The first stage is isolation. The director, as the witness A.F. told the Court, issued a decree forbidding entrance to isolation row to any member of the personnel who was not charged with surveillance of it. This decree should protect the prisoners from any abuse by guards, but, as A.F. testified (Tribunale di Asti 2012, p. 25):

It was usual, for such colleagues as C.B., M.S., D.D.B., to knock at the row door with other officers, who changed from time to time, and tell the ones on duty: would you open the door, please? I have to beat this or that guy [...] and nobody would object [...] I happened to be on duty in isolation row and faced this situation [...] nobody objected to that $[\ldots]$ we all knew that "aggressive" prisoners were dealt with like that $[\ldots]$ with this treatment $[\ldots]$ the director was rarely around, nobody else came in $[\ldots]$.

A.F. explains who the decree refers to: nurses, doctors, social workers, social care-workers, psychiatrists, psychologists, criminologists: all the professionals working in Italian prisons (personale trattamentale in Italian), who, according to penitentiary regulations, must deal daily with inmates, and are not allowed to enter isolation row. Those prisoners who go to isolation row will receive another kind of treatment, that is, beatings and other forms of abuse. Members of the treatment branch, as well as priests and volunteers, might oppose 
the abuses, or even report what happens. Finally, social workers, chaplains and volunteers do not engage in certain dispositional and situational dynamics, as they are not prison guards. It is not possible, by this token, to rely on their silence, and a strategy of denial becomes necessary. The result is a lack of certainty about the abuses and, consequently, the possibility of constructing an interpretative denial in case of a judicial report.

Internal denial could not function without working on the victims, that is, the development of a culture of denial (Cohen 2005, p. 37), which implies an active role by those who suffer the abuses. This is the second stage of internal denial, i.e., the neutralization of prisoners. Prisoners who suffer abuse can tell others, e.g., their prison mates, the doctors, the nurses, other guards, the personnel in charge of treatment, what they went through while on isolation row. In order to prevent this risk, the abusers at the Asti prison adopt specific strategies. They denigrate the statements the victims might make by telling them that nobody will believe them. A.F. states (Tribunale di Asti 2012, p. 25):

If inmates on isolation row asked to see the doctor, we reported the request, and the doctor himself often refused to visit them [...] I know who they are, he said [...] if the doctor came, and the inmates told him they wanted to report the case, the doctor or the guard discouraged them: you want to do what? Are you sure? Do you think anyone will believe you? Come on, we know you gave yourself these scars and bruises [...] don't cheat, please! You didn't give them to yourself? It was your cellmate, then $[\ldots]$ inmates often prefer to say "I fell from my cot [...] I hit the wall [...]."

This technique of neutralization goes beyond the scheme described by Sykes and Matza (1957). We are not dealing only with the abusers, that is, the prison guards, but also with the doctor who covers up the facts by explicitly denying they happened, despite evidence that there was an abuse. The offender is not, therefore, a single actor, but an articulated system of abuses involving different figures, whose outcome is multiple levels of neutralization. The prison guard did not abuse the prisoner; the doctor did not see what happened. The latter is even more serious, as doctors are bound by the Hippocratic Oath to take care of the sick and ensure they promptly recover health.

Second, the neutralization takes place through a denigration of the reputation of the victim, which relies on power relations. Prisoner have low status, and have no power, so it is useless for them to report an abuse, as nobody will believe them, particularly if they complain about the way such professional figures as prison guards and doctors treat them. This kind of neutralization relies on the active sharing of a culture of denial by the victims. Prisoners do not report abuse because they know their complaint will fall on deaf ears. The only chance they have is to state that there was no abuse, and take direct responsibility for their physical conditions.

Internal denial would not be successful without a degree of technique, consisting either of a set of practices or an accurate use of formal resources, which turns abuse into a routine practice that happens regularly, and allows the abusers the unproblematic management of beatings. A.F., in the last part of his testimony describes how the beatings were carried out (Tribunale di Asti 2012, p. 26):

Guards manage to beat the prisoners in such a way as not to leave bruises or scars [...] when beatings take place, all the cells of the row are left open, so that prisoners will testify that the officers defended themselves from aggression [...] after the beatings, the food trolley circulates across the row, food is shown to prisoners, but not delivered [...] it's easy for doctors to fill in the clinical files, and the service 
reports by the officer all share the same story [...] the inmate assaulted the guard $[\ldots]$ it was a legitimate act of defense [...].

This is the stage of normalization, the third stage of internal denial. Under normalization, both the beatings and their denial cease to be rare occurrences and become a regular practice that the actors carry out both by following specific rules and rituals, and complying with formal requirements (Welch 2007). The beating of a prisoner is not only an abuse, it is also a means of blackmailing the other prisoners. They will not report what happened to their mates because they have seen what the consequences are. Moreover, beatings are carried out in such a way as to hide the real abuse, i.e., the use of techniques that leave no scars or bruises. Other witnesses endorse A.F.'s statement; among them are prison guards and inmates at Asti prison at the time of the beatings. Other endorsing statements we consider relevant to our study come from C.S., a woman who also worked as an assistente psicopedagogico (social worker) at the prison at the time of the beatings. C.S. later left the prison because of conflicts with the director and the chief of prison guards. She accurately describes C.R.'s physical and psychological conditions after the beatings:

C.R. asked a prison guard to see me...so I was taken to the isolation row [...] he had scars and bruises all over his body [...] there was blood in his eyes [...] there was a kind of branding on the right side of his forehead [...]. I could see his chest, it seemed like he had hit something [...]. I asked him not to show me more, I was too upset [...]. He had large wounds across the ribs [...] he told me some guards had beaten him, then left him naked for days, feeding him only stale bread and water [...]. He didn't mention any names, and looked quite scared [...].

C.S. went to see the director and report the situation to him:

He told me not to worry, that he was aware of what had happened, and was going to do something about it soon $[\ldots]$.

The result of her visit to the director, turned out to be a warning:

I had just come back to my office when a guard came in and reproached me for going to the isolation row [...]. He asked me who had allowed me in [...]. Then he warned me never to dare go there again!

C.S.'s testimony tells us about the borders and the hierarchies working inside the Asti prison. Despite the fact that directors are the heads of Italian prisons, the effective power lies in the hands of prison guards, who are in charge of discipline, and choose discretionally how to deal with inmates. This twist of formal rules is possible because directors are likely to transfer to another prison every 3 years, while prison guards, unless they request a transfer, work long term in the same prison. This difference makes it possible to displace hierarchies, and puts prison guards in a prominent position. They have a deeper knowledge both of the prison and of local reality, and directors often follow their advice. Therefore, the prison guards, particularly those who have worked in a prison for a long time and are in the middle-high ranks, decide which actors can become aware of what happens on isolation row, thus drawing the borders of external denial. Social workers, as well as newly hired prison guards, cannot participate if suspected of being unreliable.

This is the fourth stage of internal denial, which is subjugation of other professional actors through force relations inside prisons. This hierarchical dynamic is possible thanks to the extent to which prisons are isolated from the rest of civil society. 
This is why the techniques of internal denial are usually successful, as public opinion rarely concerns itself with daily life in prison. The case of Asti is relevant not only for the seriousness of the abuses, but also because those abuses were revealed to the public, and thus swept away the cobweb of shared denial. Once the magistrates dismantle the border of denial, it becomes necessary to work out other strategies to justify abusive behaviors. This is the case of external denial, which we will discuss it in the next section.

\section{External Denial: The Observers and the Offenders}

The trial against the alleged offenders started in 2011, as the result of an enquiry and of an awareness campaign promoted by Antigone and A Buon Diritto (Manconi 2012), two Italian associations that had been working for years in the domain of the penal system. The former also provided the beaten inmates with a lawyer. The trial created a new frame, with different roles and rules from the ones in force in prison. Beatings and isolation were no longer routine treatment inmates must suffer. The triangular set of behaviors, expectations and patterns that observers, offenders, and victims shared was shattered because of the external pressure of law and public opinion. Inmates moved to the side of the accusers, thus making it necessary for the guards, the doctors, and the director of the Asti prison to work out a new strategy of denial, which relied mostly on the interpretation of facts, and attempted to justify both the beatings and the other abuses as matters of security and selfdefense.

The initial strategy focused on the literal denial of the abuses through the discrediting of A.F., C.S., and M.T., and of the victims. D.D.B., one of the defendants, states that,

There was no beating [...]. I didn't see any sign of it [...] inmates use to ruin the cells, that's why we keep them bare [...] it's higher ranks who decide on solitary confinement $[\ldots]$ not us [...]. A.F. is a liar, his fellow inmates use to call him The Lie [...].

D.R., the doctor, follows the same path:

I regularly go to visit the inmates on isolation row, and I report every critical situation [...] I can remember clearly what happened that time, and I am sure there was no beating at all [...]. A.F. and M.T. [another prison guard who declared that the beatings happened] are just liars [...].

The attempt to deny the beatings was not successful, as the Court allowed the evidence of the wiretaps we analyzed at the beginning. A change of strategy therefore became necessary, as the statements of G.M., the director of the prison, show:

An inmate had assaulted a guard [...]. I happened to see other assaults, and I know how negative the consequences can be for the guard [...] I can remember there was much fuss about it [...]. I can't remember the beatings [...]. We take inmates to solitary when they prove to be dangerous [...] there are no windows, they can use the glass to injure themselves [...]. I have seen more than 20 officers ending up in the hospital because inmates beat them [...]. It often happens that doctors forget to report bad physical conditions. I agree, it's not good to act like that [...].

The director works out an interpretative denial based on the shifting of the focus. Prisoners are the real offenders, prison officers are the victims. Bare cells, illegal as they are, protect both the prison guards from aggression, and the prisoners from self-inflicted injuries and 
attempted suicide. As Cohen (2005, p. 136) points out, we are facing an implicit interpretative denial, which is articulated in five stages: uprightness, necessity, denial of the victims, contextualization, and comparison. The first stage consists of the denunciation of aggression that guards suffer, and on the need to cope with them to assure that inmates respect the rules, and serve their time without being aggressive. The second stage relates to the need to justify the existence of bare cells. They are common in all Italian prisons, and serve well the purpose of protecting both officers and inmates. The director moves then to the third stage, as he focuses on the aggression officers suffer from inmates as the real problem of the Asti prison. The director depicts prison as a dangerous place (fourth stage), in which the lives of guards are constantly at risk, requiring the implementation of measures that may appear to be illegal to the eye of nonprofessionals, but are perfectly normal to those who work within the penal system. The director never explicitly denies the abuses, but, by stressing the context of aggressiveness, he suggests that any possible abuse is an act of self-defense on the part of prison guards, thus paving the way for the last stage. If prison is a violent place, everyone operating in the penitential domain must act violently. Another wiretap of a conversation between C.B. and L.P., who was a newly recruited prison officer, illustrates this attitude, when the former tells the latter:

If you want to do this job, you've got to be tough, you've got to play the rogue. Let the rogue within you emerge, beat them, and you'll gain respect (Tribunale di Asti 2012, p. 54).

Violence underpins penitentiary practices. It goes beyond the rule of law, as the relations between guards and inmates are relations of force. C.B. and most of his colleagues, therefore, regard the need to gain respect as the principal professional skill to develop, in light of the aggressive environment they work in (Zimbardo 2009, p. 392). Its practice can be either implicit or explicit. For example, isolation rows and bare cells constitute a sort of implicit violence, since they imply further restrictions added to the limitation of freedom inmates suffer by definition. The context justifies it as a routine practice, though it is not legal. Both the officers and the director must thus dance around the issue of illegality, and they do so by choosing the path of implicit denial, which hides violence under the veils of needs and practices, and justifies the use of violence in a violent environment. As a result, other witnesses, mostly prison guards, will follow the path taken by the director, an external denial that relies on interpretation and implicitness. All of them will justify their actions mainly through contextualization. Duties provide the background for their justification.Moving along this path, the chief of prison guards, T.C., states that,

I comply with my duties. I've never taken inmates to isolation row without the consent of the director. This is the rule. It was the same when all this stuff happened [...]. I didn't see any violence, I've never heard that something like that ever occurred [...]. In any case, isolation is a routine practice! A long-running practice. We surely don't do it to protect inmates from officers, but, rather, the other way round. On the other hand, better, to prevent any suicide or self-inflicted injury by the prisoners. You know, inmates could also agree among themselves about what to say if they are ever questioned by someone (Tribunale di Asti 2012, p. 46).

T.C. continues to use the strategy of implicit denial, as he emphasizes his duties, keeps insisting on the point that officers are the victims, and repeats that isolation (and bare cells) are a common practice in the prison system. His statements derive from the dispositional and situational forces that shape the group identity of offenders. Their idea of prison is rooted in the assumption that prisoners and officers are two different and conflicting 
groups. The judge, though, reads a document to T.C. in which the officers are ordered to take A.C. and C.R. to isolation row because of the fact that "a judicial enquiry is underway" (Tribunale di Asti 2012, p. 46), and "to comply with their duties and safeguard the prisoners." The judge asks T.C. if the aim of isolation, in his orders, was to protect the inmates from themselves, and the chief insists:

Yes, did you see what A.C. did?

The statement of T.C. contradicts the rules of isolation. Officers must take shoestrings and belts from prisoners who are serving a disciplinary punishment, but A.C. still wears both, so that he could attempt suicide. The chief officer gives an annoyed answer:

It was a moment of tension; I didn't have time to think of the belt and the shoestrings!

Other officers confirm they always take belts and shoestrings off, thus endorsing the thesis of the prosecutor that T.C. and his colleagues are trying to deny what happened. Their statements emphasize that prisoners pose a threat to both officers and to themselves. V.D.S., for example, says of C.R.:

He had a razor blade! Hell, the blade! You know, in prisons, blades are a very common weapon among inmates. When they use it, they cut your face, so that you keep the scar for the rest of your life! So that every morning you look at yourself in the mirror and [...] it's a nightmare for us! I remember I had the feeling that A.C. was ready to carve me up!

Like both the director and the chief officer, V.D.S. contextualizes the reality of prison, portraying a nightmarish reality of violent inmates, thus implicitly justifying the need for prison guards to defend themselves in order to avoid both physical threats and mere "feelings" of being at risk. It is the inmates who are violent, and officers need to do something about it. Fear means that "something" remains undetermined, unruly, discretionary, and justified. It is easy to find in these statements a training-related problem. To the extent that officers follow the pattern of group identity, they will regard prisoners as enemies, and beatings, tortures and any other abuse will be the legitimate working strategies inside prisons.

When inmates are not a direct threat to guards, they can harm themselves, even by refusing food:

We didn't leave C.R. without food. He just kept refusing it [...] he wanted to take his life (Tribunale di Asti 2012, p. 52).

Officers worry about suicide also because inmates are under their surveillance, and such a tragic event could result in disciplinary action against them. In the final analysis, group subculture leads prison guards to view acts such as self-injury, refusal to eat, or even suicide as conflicting strategies enacted by inmates. Offenders speak a different language from that of law and public opinion. Their denial of serious offences is indeed a refusal of a culture that relies on the respect and enforcement of rights and humane treatment in prisons.

In any event, this strategy of external denial that both the officers and the director try to carry out is bound to fail. The victims, supported by the various NGOs who are paying their lawyers, have decided to talk about what happened. Moreover, the contradictory statements of prison guards, as well as the wiretapped conversations, have contributed to evidence that guards at the Asti prison tortured A.C. and B.R. L.P., a prison officer initially 
admitted his guilt (because of the wiretapped conversation between A.B. and him), but later recanted. Like the director and his chief, he attempts a contextualization of the facts:

You don't know what a prison is like. Let me tell you that a prison is a closed structure, everything you say bounces back, and everyone, at the end of the day, knows about it. My idea was to circulate a few stories, but [...] I couldn't imagine all this happened [...] I invented all these stories just because I would have liked that something like that could happen [...] I was in the car with A.B. that day, I don't know why $[\ldots]$.

The last statement tells us more about denial. A closed structure, where stories circulate and overlap, makes denial possible. No one from the outside can see, and the constant contradictions allow a quick cover-up of abuse and violence. A lack of external and internal control makes it possible to deny the use of violence. As a result, one act of violence leads to the next. Unless, as in this case, a casual glimpse from the outside opens the way to a degree of awareness that makes the offenders accountable and empowers the victims.

\section{Conclusions}

The case we have discussed shows us how complex the denial of abuse can be. First, it is necessary to create a network of shared practices, values, and habits for it to be successful. This network is embedded in force relations and hierarchies, out of which a culture of denial will develop. On the one hand, victims, observers, and offenders might share the idea that prison is a rough environment, one which obviates the set of formal rules. On the other hand, victims have no chance of negotiating with the other actors because they have low status, a low degree of both material and symbolic resources, and are forced to accept the culture of violence and aggression if they want to survive their sentence. There were 59 suicides in Italian prisons in 2013 (www.ristrettiorizzonti.org, 2013), one for every thousand prisoners, a testament to how harsh the conditions of Italian prisoners are. Despite being in a better position than the victims, observers, that is the director and the professionals working in prisons, accept abuses and denials, because they agree that the inmates have a bad reputation, and because they can work for short terms. Directors can transfer every 3 years, doctors go to prison for only a few hours a day, while guards (the offenders) work for many years, and have a thorough knowledge both of all the inmates and of the relational dynamics that take place in prison. This, as well as their entitlement to use force, puts the prison guards in a prominent position. The possibility of using force makes them feared by the inmates, and necessary to the top ranks. The director, the doctors, the nurses, and the social workers need them to maintain order and to relate information about the inmates. Such a degree of knowledge and power (Foucault 1976), allows prison guards to use formal rules in "flexible" ways, and to choose how to act, that is, to justify abuses in the name of order and discipline by shifting the blame onto the victims.

Denial is flexible, as the actors can change according to the context in which they act. We have discussed the shift from internal to external dynamics. Neither the offenders nor the observers admitted their complicity. Rather, they appealed to the peculiarities of the penal institution by emphasizing how dangerous inmates can be. Their implicit denial was, in this respect, a sort of implicit admission, as though they were trying to justify their actions by recourse to the culture of law and order, which has been popular in Italian 
society in recent years. If prisons are a place where people are punished, this punishment must be as harsh as possible, since inmates put at risk the lives of other persons who live and work honestly.

Their strategy was unsuccessful, mainly for two reasons: first, the wiretaps revealed not only the cruelty with which guards described and legitimized their actions, but also that they were involved in other illegal affairs, such as drug smuggling. The contradictory statements of defendants added further difficulty to the strategy of depicting the beatings in the Asti prison as a mere struggle between good and evil. Second, the mobilization of civil society (Kauzlarich et al. 2001) boosted efforts to shed light on this case, and brought it to the fore in public opinion.

The Asti case shows us that violence against prisoners is possible under four conditions: the first is that prison continues to be hidden from the rest of society. The second is that nobody reacts against it. The third is that offenders enjoy impunity for what they do. The last is that prisoners rarely report what they suffer, because their isolation from society makes it preferable for them to join the culture of denial. Hence it becomes necessary (Austin et al. 2001) to implement those measures that make public opinion aware of what happens inside prisons, in order to mobilize civil society, and to prompt offenders to behave in full respect of the law. The institution of an Independent Prison Ombudsman and the approval of an anti-torture law by the Parliament would be the first steps in this direction. This would help monitor both abuse and abusers, and shed light on even more serious violations. Academy has also an important part to play. The development of convict criminology studies in Italy would be an important step to undertake. A qualitative criminological analysis, based on the experience of both convicts and ex-convicts (Richards 2013), would help the research on prisons to get rid of the framework shaped by the vocabulary of criminal justice administrators, so as to give way to the point of view of the victims of prison abuses. In other words, the development of convict criminology in Italy would be helpful. To conclude, a different training strategy for prison guards, focused more on the rights of prisoners, could help to radically change the patterns of relations between them and the detainees. We are aware of the fact that prison and violence march hand in glove, though this does not obviate the real need for radical reform of the penal system. But that will be a long and rocky road to march.

\section{References}

Anastasia, S. (2013). Metamorfosi penitenziarie. Carcere, pena e mutamento sociale. Rome: EDIESSE.

Austin, J., Bruce, M. A., Carrol, L., Mc Call, P. L., \& Richards, S. C. (2001). The use of incarceration in the United States. Critical Criminology, 10(1), 17-41.

Cohen, S. (2005). Stati di negazione. Rome: Carocci.

De Gregorio, C. (2005). Non lavate questo sangue. Rome: Editori Riuniti.

Foucault, M. (1976). Sorvegliare e punire. Turin: Einaudi.

Goffmann, E. (1982). Asylums. Turin: Einaudi.

Goldson, B. (2006). Damage, harm and death in child prisons: Questions of abuse and accountability. The Howard Journal of Criminal Justice, 45(5), 449-467.

Gonnella, P. (2013). La tortura in Italia. Rome: DeriveApprodi.

Irwin, J. (2004). The warehouse prison: Disposal of the new dangerous class. Oxford: Oxford University Press.

Kauzlarich, D., Matthews, R. A., \& Miller, W. J. (2001). Toward a victimology of state crime. Critical Criminology, 10(1), 173-194.

Liebling, A., \& Arnold, H. (2005). Prisons and their moral performance. A Study of values, quality and prison life. Oxford: Oxford University Press. 
Manconi, L. (2012). Quando hanno aperto la cella. Rome: Editori Riuniti.

Mosconi, G., \& Sarzotti, C. (2005). Dentro ogni carcere. Turin: L'Harmattan.

Richards, S. C. (2013). The new school of convict criminology thrive and mature. Critical Criminology, 21(3), 375-387.

Sykes, G., \& Matza, D. (1957). Techniques of neutralization: A theory of deviance. American Sociological Review, 22(6), 664-670.

Tribunale di Asti, sentenza 23/04/2012.

Welch, M. (2007). Fare l'impensabile. Genealogia della tortura moderna. Studi sulla Questione Criminale, 5(2), 41-64.

Zimbardo, P. (2009). Effetto Lucifero. Cattivi si diventa? Milan: Il Saggiatore.

Sitography

www.abuondiritto.it

www.associazioneantigone.it

www.coe.cpt.int

www.larepubblica.it

www.risterettiorizzonti.org 